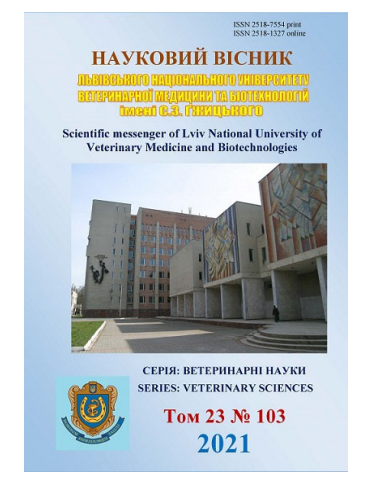

\author{
Науковий вісник Дьвівського національного університету \\ ветеринарної медицини та біотехнодогій імені С.3. Гжицького. \\ Серія: Ветеринарні науки \\ Scientific Messenger of Lviv National University \\ of Veterinary Medicine and Biotechnologies. \\ Series: Veterinary sciences
}

UDC 619:636.598:591.445

\title{
Features of the microscopic structure of the adrenal gland of geese
}

\author{
V. Prokopenko, T. Kot \\ Polissia National University, Zhytomyr, Ukraine
}

Article info

Received 17.06.2021

Received in revised form 21.07.2021

Accepted 22.07.2021

Polissia National University, Stary Boulevard, 7, Zhytomyr, 10008, Ukraine.

Tel.: +38-098-246-45-32

E-mail:ogp.zt.2013@gmail.com
Prokopenko, V., \& Kot, T. (2021). Features of the microscopic structure of the adrenal gland of geese. Scientific Messenger of Lviv National University of Veterinary Medicine and Biotechnologies. Series: Veterinary sciences, 23(103), 10-14. doi: 10.32718/nvlvet10302

The study of the morphology of the adrenal gland of birds is one of the most critical issues of modern biology and veterinary medicine cause its solution contributes to the scientific justification of technologies for rearing, using, and treating birds. The work aims to clarify the features of the microscopic structure of the adrenal gland of geese. As a peripheral organ of the endocrine system, the adrenal gland affects the growth and differentiation of tissues, regulates water, protein, carbohydrate, fat, and mineral metabolism, the body's resistance to infections, intoxication, stress, and other factors. During research were used histological indagation methods. It was found that blood vessels, clusters of nerve cells are registered in the capsule of the adrenal gland of geese. Nodes of the sympathetic nervous system are registered outside it. Connective tissue septa with hemocapillaries extend from the capsule to the adrenal parenchyma, which is represented by intertwined cell strands of interrenal and suprarenal tissues. The narrow spaces between these cell strands are filled with layers of loose fibrous connective tissue with sinusoidal hemocapillaries and venous sinuses. The subcapsular layer, peripheral and central zones are recorded on the incision of the adrenal gland. The adrenal vein is localized in the central zone. The subcapsular zone is mainly represented by cells of suprarenal tissue, the peripheral and central zone - by cells of interrenal tissue. Suprarenal tissue cells have a polygonal shape, basophilic cytoplasm, and a rounded, centrally located nucleus. Cells of interrenal tissue are columnar or cubic, have eosinophilic colored cytoplasm, a round or oval nucleus placed eccentrically. Venous sinuses are localized in the central and peripheral zones of the adrenal gland. Their wall is thin, formed by flat endotheliocytes, bounded by groups of cells of interrenal and suprarenal tissues. As a result, established microscopic structural features of the adrenal gland of geese can be used to formulate the base of its typical morphological characteristics, which give a possibility to assess the Morpho-functional essential state of the bird adrenal gland of this species by the influence of various factors and pathologies, in perspective of following researches - the exploration of morphometric parameters of the structural components of the adrenal gland of geese.

Key words: geese, microscopic examinations, interrenal and suprarrenal tissues, endocrinocytes, venous sinuses.

\section{Особливості мікроскопічної будови надниркової залози гусей}

\author{
В. С. Прокопенко, Т. Ф. Кот
}

Поліський начіональний університет, Житомир, Украӥна

\footnotetext{
Дослідження морфології надниркової залози птахів є актуальною проблемою сучасної біології та ветеринарної медицини, оскільки ї̈ вирішення сприяє науковому обтрунтуванню технологій вирощування, використання та лікування птахів. Мета роботи встановити особливості мікроскопічної будови надниркової залози гусей. Надниркова залоза як периферичний орган ендокринної системи впливає на ріст і диференціювання тканин, регулює водний, білковий, вуглеводний, жировий і мінеральний обміни, впливає на резистентність організму до інфекиій, інтоксикації, стресу та інших факторів. В ході дослідження були використані гістологічні методи дослідження. Встановлено, що у капсулі надниркової залози гусей реєструються кровоносні судини, скупчення нервових клітин, а зовні - вузли симпатичної нервової системи. Сполучнотканинні перегородки з гемокапілярами відходять від капсули в паренхіму надниркової залози, яка представлена переплетиними клітинними тяжсами інтерреналової та супрареналової тканин.
} 
Вузькі проміжки між цими клітинними тяжами заповнені прошарками пухкої волокнистої сполучної тканини з синусоїдними гемокапілярами і венозними синусами. Субкапсулярний шар, периферична і центральна зони реєструються на розрізі надниркової залози. В иентральній зоні локалізується надниркова вена. Субкапсулярна зона представлена переважно клітинами супрареналовоі тканини, периферична і центральна зона - клітинами інтерреналової тканини. Клітини супрареналової тканини мають полігональну форму, базофільну ичтоплазму, округле, иентрально розмімене ядро. Клітини інтерреналової тканини стовпчастої або кубічної форми, мають еозинофільно забарвлену циитоплазму, округле або овальне ядро, шуо розмімене ексцентрично. Венозні синуси локалізуються в центральній і периферичній зонах надниркової залози. Їх стінка тонка, утворена плоскими ендотеліоцитами, обмежена групами клітин інтерреналової та супрареналової тканин. Встановлені особливості мікроскопічної будови надниркової залози гусей можна використовувати для створення бази ї̈ нормальної морфологічної характеристики, шо дасть можливість робити оцінку морфо-функціонального стану надниркової залози птахів даного виду за впливу різних факторів $і$ за патології. У перспективі подальших досліджень - вивчення морфометричних показників структурних компонентів надниркової залози гусей.

Ключові слова: гуси, мікроскопічні дослідження, міжниркові та надниркові тканини, ендокриноцити, венозні пазухи.

\section{Вступ}

Надниркова залоза як орган в людини була відкрита італійським лікарем і анатомом Бартоломео Свстахісм у 1563 році. Протягом багатьох років будова i функція надниркової залози вивчалась у ссавців, а у 1719 році професор анатомії з Болонії (Італія) Антоній Вальсальва виявив анатомічний зв'язок між наднирковою і статевими залозами у птахів, зокрема голубів та соколів (Kot et al., 2021).

Нині морфологія надниркової залози птахів $є$ актуальною проблемою біології та ветеринарної медицини, оскільки іiі вирішення має практичне значення для оцінки морфо-функціонального стану птахів в певні періоди життя, що необхідно для наукового обгрунтування технологій їх вирощування, використання та лікування (Matos, 2008). Багато досліджень науковців присвячено вивченню будови структурних компонентів надниркової залози птахів за їхнього експериментального утримання і годівлі, при захворюваннях (Moreng et al., 1980; Błachuta \& WrońskaFortuna, 2012; Muller et al., 2015; Abeena et al., 2017; Qureshi et al., 2020).

При вивченні морфології надниркової залози птахів у нормі особливий інтерес у дослідників викликають питання зональності паренхіми залози, клітинного складу інтерреналової та супрареналової тканин, розміщення нейронів симпатичної нервової системи та лімфоїдних вузликів у залозі (Kober et al., 2012; Fathima \& Lucy, 2014; Moawad \& Hassan, 2017; Kot et al., 2020). Особливо це стосується птахів із ряду гусеподібних. 3 цього питання у спеціальній літературі $\epsilon$ суперечливі дані, які обмежені певними віковими групами птиці та потребують подальших більш глибоких досліджень (Elzoghby, 2010; Fedotov, 2013; Fathima \& Lucy, 2014; Jabbar et al., 2021).

Мета досліджень - встановити особливості мікроскопічної будови надниркової залози гусей. Для досягнення мети необхідно було вирішити такі завдання: 3'ясувати поділ надниркової залози на зони; визначити мікроскопічну будову супрареналової та інтерреналової тканин; встановити локалізацію венозних синусів.

\section{Матеріл і методи досліджень}

Робота є фрагментом НДР “Морфологія надниркової залози птахів" (номер державної реєстрації № 0120U101089), виконана на кафедрі анатомії і гіс- тології факультету ветеринарної медицини Поліського національного університету.

Надниркову залозу відібрали від свійських гусей віком 330 діб $(\mathrm{n}=6)$ з дотриманням вимог “Свропейської конвенції про захист хребетних тварин, які використовуються для експериментальних і наукових цілей” (Страсбург, 1986 р.), ухвали Першого національного конгресу з біоетики (Київ, 2001 р.) і Закону України № 692 "Про захист тварин від жорстокого поводження" від 21.02.2006 p.

Забій гусей здійснювали після інгаляційного передозування хлороформом методом гострого знекровлення шляхом перерізання підключичної артерії. Після розтину грудочеревної порожнини гусей проводили анатомічне препарування надниркової залози (Brooks Brownlie \& Munro, 2016).

Для проведення гістологічних досліджень застосовували загальноприйняті методи фіксації матеріалу і виготовлення гістозрізів. Останні фарбували гематоксиліном Караці та еозином (Mulisch \& Welsch, 2015). Мікрофотографування гістологічних препаратів здійснювали за допомогою цифрової фотокамери, вмонтованої у мікроскоп Primo Star (Carl Zeiss, Німеччина) і підключеної до персонального комп'ютера.

\section{Результати та їх обговорення}

Гістологічні дослідження показали, що надниркова залоза гусей вкрита капсулою, від якої в паренхіму відходять сполучнотканинні перегородки з численними гемокапілярами. В капсулі реєструються кровоносні судини і скупчення нервових клітин, що також зазначили у своїх роботах (Moawad \& Randa, 2017), які досліджували мікроскопічну будову надниркової залози курей. Місцями зовні капсули надниркової залози гусей розміщуються вузли симпатичної нервової системи (рис. 1). Moghadam \& Mohammadpour (2017) реєстрували нервові ганглії у паренхімі надниркової залози цесарок.

Паренхіма надниркової залози гусей представлена інтерреналовою і супрареналовою тканинами, клітинні тяжі яких переплітаються між собою (див. рис. 1), що характерно і для птахів інших видів (Kober et al., 2012; Moawad \& Randa, 2017). Вузькі проміжки між клітинними тяжами заповнені прошарками пухкої волокнистої сполучної тканини, в яких реєструються синусоїдні гемокапіляри та венозні синуси.

Згідно з дослідженнями Tang et al. (2009), Jabbar et al. (2021), на сагітальному розрізі надниркової залози 
страусів, качок і цесарок розрізняється дві зони: периферична (субкапсулярна) і внутрішня (центральна). У наднирковій залозі гусей нами зареєстровано три ділянки: субкапсулярний шар, периферичну і центральну зони, що підтверджує результати досліджень інших авторів (Humayun et al., 2012; Kober et al., 2012; El-Desoky \& El-Zahraa, 2021), які досліджували надниркову залозу курей, цесарок і перепілок. В центральній зоні надниркової залози гусей реєструється надниркова вена (див. рис. 1).
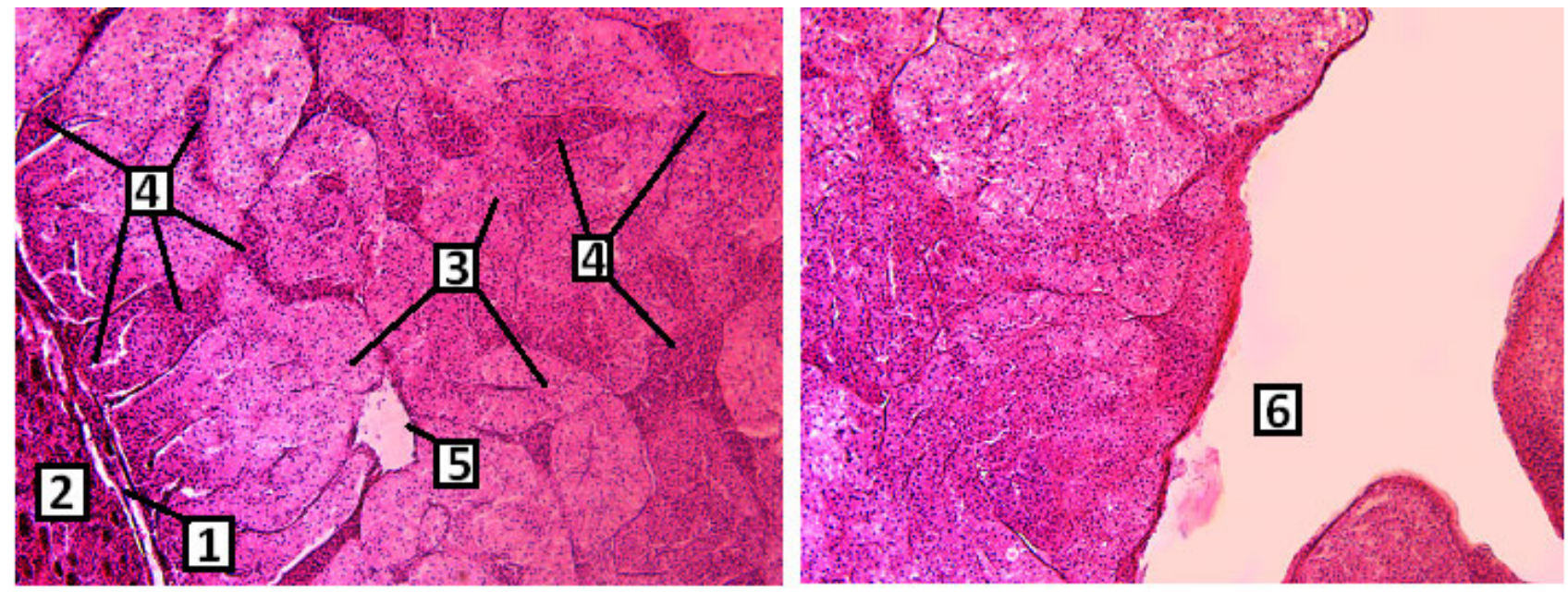

Рис. 1. Фрагмент мікроскопічної будови надниркової залози гуски віком 330 діб: 1 - капсула; 2 - вузол симпатичної нервової системи; 3 - інтерреналова тканина; 4 - супрареналова тканина; 5 - венозний синус;

6 - просвіт надниркової вени. Гематоксилін Караці та еозин. $\times 100$

Субкапсулярна зона надниркової залози гусей сформована переважно з клітин супрареналової тканини. Вони утворюють тяжі у вигляді дугоподібних канатиків (див. рис. 1), що відмітили й інші дослідники (Ye et al., 2018; Jabbar et al., 2021), але суперечить даним Kober et al. (2012) i Moghadam \& Mohammadpour (2017) про формування субскапулярного шару надниркової залози курки і цесарки виключно $з$ клітин супрареналової тканини.

У периферичній і центральній зонах надниркової залози гусей переважає інтерреналова тканина. Її клітини формують циліндричні тяжі у вигляді петель, між якими реєструються безформні острівці клітин супрареналової тканини.

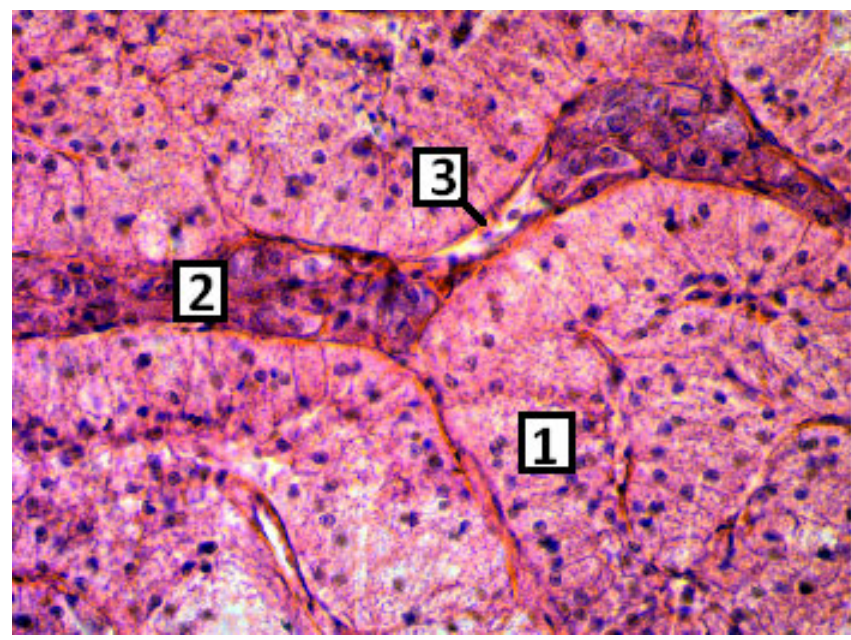

Щодо морфологічної характеристики клітин супрареналової та інтерреналової тканин надниркової залози гусей, ендокриноцити першої мають переважно полігональну форму, базофільну цитоплазму, округле, центрально розміщене ядро. Клітини інтерреналової тканини надниркової залози гусей стовпчастої або кубічної форми, мають еозинофільно забарвлену цитоплазму, округле або овальне ядро, що розміщене ексцентрично (рис. 2). Такі ж клітини двох груп (ацидофільні та базофільні) дифференціювали Elzoghby (2010) в наднирковій залозі гусей, що суперечить даним Fedotov D. N. (2013) i Prabhavathi et al. (2011) про чотири типи клітин інтерреналової тканини надниркової залози качок і цесарок.

Рис. 2. Фрагмент мікроскопічної будови надниркової залози гуски віком 330 діб: 1 - клітини інтерреналової тканини; 2 - клітини супрареналової тканини; 3 - синусоїдний гемокапіляр; 4 - просвіт венозного синуса. Гематоксилін Караці та еозин. × 400 
Як зазначено вище, між окремими клітинними тяжами інтерреналової та супрареналової тканин надниркової залози гусей спостерігаються синусоїдні гемокапіляри (див. рис. 2), які, на думку Tang et al. (2009), утворюються в результаті злиття венозних і артеріальних капілярів. Щодо венозних синусів, наші дослідження показали, що вони реєструються як в центральній, так і периферичній зонах надниркової залози гусей, що суперечить даним інших авторів (Elzoghby, 2010; Moghadam \& Mohammadpour, 2017), які реєстрували їх тільки в центральній зоні надниркової залози гусей і цесарок. Стінка венозних синусів надниркової залози гусей тонка, утворена плоскими ендотеліоцитами, обмежена групами клітин інтерреналової та супрареналової тканин (див. рис. 2).

\section{Висновки}

Особливості мікроскопічної будови надниркової залози гусей (поділ паренхіми залози на зони, клітинний склад інтерреналової та супрареналової тканин, розміщення венозних синусів) можна використовувати для створення бази іiі нормальної морфологічної характеристики, що дасть можливість робити оцінку морфо-функціонального стану надниркової залози птахів даного виду в умовах впливу різних факторів та за патології.

Перспективи подальших досліджень. Вивчення морфометричних показників структурних компонентів надниркової залози гусей.

\section{References}

Abeena, B., George, A., Shejir, R., Mohammed, N., \& Manomohan, C. (2017). Pathology of endocrine glands of layer chicken in experimental aflatoxicosis. Indian $\mathrm{J}$ Vet Pathol, 41(2), 163-166. doi: 10.5958/0973970X.2017.00041.4.

Błachuta, M., \& Wrońska-Fortuna, D. (2012). Changes in estrogen receptor ER $a$ and ER $\beta$ expression in chicken (Gallus domesticus) adrenal gland during short-fasting and refeeding. Folia Biol, 60(3-4), 199-203. doi: 10.3409/fb60 3-4.199-203.

Brooks Brownlie, H., \& Munro, R. (2016). The veterinary forensic necropsy: a review of procedures and protocols. Vet Pathol, 53(5), 919-928. doi: 10.1177/0300985816655851.

El-Desoky, S. M., \& El-Zahraa, F. M. (2021). Morphological and histological studies of the adrenal gland in the Japanese quail (Coturnix japonica). Microsc Res Tech, 84(10), 2361-2371. doi: 10.1002/jemt.23791.

Elzoghby, I. M. (2010). Light and electron microscope studies of the adrenal glands of the Egyptian Geese (Alopochen aegyptiacus). Lucrari Stiintifice Med Vet, 12(1), 195-203.

Fathima, R., \& Lucy, K. (2014). Morphological studies on the adrenal gland of kuttanad ducks (Anas platyrhynchos domesticus) during post hatch period. J Agricult Vet Sci, 7(6), 58-62. doi: 10.9790/2380-07635862.

Fedotov, D. N. (2013). Vozrastnye gistologicheskie perestrojki nadpochechnikov u krjakvy, obitajushhej v severnoj chasti Belarusi. Uchenye zap. Vytebskoi hos. akad. vet. med., 49(2), 112-115 (in Russian).

Humayun, K. A. K. M., Aoyama, M., \& Sugita, S. (2012). Morphological and histological studies on the adrenal gland of the chicken (Gallus domesticus). J Poult Sci, 49(1), 39-45. doi: 10.2141/jpsa.011038.

Jabbar, I. A., Kareem, H., \& Abdulghafoor, R. (2021). Histomorphological Comparative Study of the Adrenal Glands in Local Guinea Fowl (Numida Meleagris) and Muscovy duck (Cairina Moschata Domestica). Ann Romanian Soc Cell Biol, 25(3), 4360-4369.

Kober, H., Masato, A. \& Shoei, S. (2012). Morphological and Histological Studies on the Adrenal Gland of the Chicken (Gallus domesticus). J Poult Sci, 49(1), 39-45. doi: 10.2141/jpsa.011038.

Kot, T. F., \& Prokopenko, V. S. (2020). Osoblyvosti morfologii' nadnyrkovoi' zalozy kurej. Naukovi goryzonty, 5(90), 82-88. doi: 10.33249/2663-21442020-90-5-82-88 (in Ukrainian).

Kot, T. F., Rudyk, S. K., Huralska, S. V., Kot, T. F., \& Khomenko, Z. V. (2021). Doslidzhennia morfolohii nadnyrkovoi zalozy iz davnyny do sohodennia. Nauk. visnyk LNUVMB im. S. Z. Gzhytskoho, 23(101), 75-81. doi: 10.32718/nvlvet10113 (in Ukrainian).

Matos, R. (2008). Adrenal steroid metabolism in birds: anatomy, physiology and clinical considerations. Vet Clin North Am: Exot Anim Pract, 11(1), 35-57. doi: 10.1016/j.cvex.2007.09.006.

Moawad, U., \& Hassan, M. R. (2017). Histocytological and histochemical features of the adrenal gland of Adult Egyptian native breeds of chicken (Gallus Gallus domesticus). J Basic Appl Sci, 6(2), 199-208. doi: 10.1016/j.bjbas.2017.04.001.

Moghadam, D. P., \& Mohammadpour, A. (2017). Histomorphological and stereological study on the adrenal glands of adult female guinea fowl (Numida meleagris). Comp Clin Pathol, 26(3), 1227-1231. doi: 10.1007/s00580-017-2514-3.

Moreng, G. R., Cain, J. R., \& Warner, R. L. (1980). The effect of adrenal glands on ovulation in Japanese quail (Coturnix coturnix japonica). J Poult Sci, 59(12), 2760 2764. doi: $10.3382 /$ ps.0592760.

Mulisch, M., \& Welsch, U. (2015) Romeis - mikroskopische technik. Heidelberg: Spektrum Akademischer Verlag. 620 p. doi: 10.1007/978-3-642-55190-1.

Muller, B. R., Medeiros, H. A. S., de Sousa, R. S., \& Molento, C. F. M. (2015). Chronic welfare restrictions and adrenal gland morphology in broiler chickens. J Poult Sci, 94(4), 574-578. doi: 10.3382/ps/pev026.

Prabhavathi, M., Sabiha, B., Venkatesan, S., \& Leela, V. (2011). Electron microscopical study of adrenal gland in guinea foul. Indian J Animal Resea, 45(3), 215-218. URL: https://www.indianjournals.com/ijor.aspx?target=ijor:ijar1\& volume $=45 \&$ issue $=3$ \&article $=012$.

Qureshi, S., Khan, M. N., Shafi, S., Mir, M. S., Adil, S., \& Khan, A. (2020). A study on histomorphology of adrenal gland in broiler chickens subjected to cold stress and its ameliorating remedies. Int J Curr Microbiol App Sci, 9(4), 1160-1168. doi:10.20546/ijcmas.2020.904.137.

Tang, L., Peng, K.-M., Wang, J.-X., Luo, H.-Q., Cheng, J.Y., Zhang, G.-Y., Sun, Y.-F., Liu, H.-Z., \& Song, H. (2009). The morphological study on the adrenal gland of 
Науковий вісник ЛНУВМБ імені С.З. Гжицького. Серія: Ветеринарні науки, 2021, т 23, № 103

African ostrich chicks. Tissue Cell, 41(4), 231-238. doi: 10.1016/j.tice.2008.11.003.

Ye, L. X., Wang, J. X., Li, P., \& Zhang, X. T. (2018). Distribution and morphology of ghrelin immunostained cells in the adrenal gland of the African ostrich. Biotech Histochem, 93(1), 1-7. doi: 10.1080/10520295.2017.1372631. 